Румена Ѓердовска

Ј3У Универзитетска клиника за инфективни заболувања и фебрилни состојби, Скопје

\title{
СОЦИЈАЛНА РАБОТА СО ЛУЃЕ КОИ ЖИВЕАТ СО ХИВ (ЛЖХИВ) ВО РЕПУБЛИКА МАКЕДОНИЈА
}

UDK: 364-787.9:616.98:579.828.7]-052

\section{Почеточите на ХИВ епидемија - здравствени и социјални аспекти}

Повеќе од 30 години светот се соочува со предизвикот наречен ХИВ/СИДА. Ако 80-тите години на минатиот век беа години на мистерија, страв и смрт поврзани со болеста, новиот милениум донесе една нова надеж за сите луѓе кои се погодени од болеста. И додека во 90-тите години на 20. век во европските земји и светот воопшто, социјалните работници биле во првите „борбени редови“ во справувањето со ХИВ епидемијата, во Република Македонија едвај се појавувале првите активисти и волонтери кои пружале помош и поддршка на пациентите и нивните семејства .

Прашањето на третман, грижа и поддршка на луѓето кои живеат со ХИВ (ЛЖХИВ) во Македонија добива нова димензија во последните десет години. Имено, со воведувањето на третманот за лекување на ХИВ инфекцијата (т.н. високо активна антиретровирусна терапија- ВААРТ) ова заболување започнува да претставува една хронична состојба, со која може да се живее долг и квалитетен живот. При тоа, успешното менаџирање на здравствените проблеми на пациентите е пропратено со многубројни психосоцијални проблеми, со што ХИВ/СИДА сѐ повеќе станува социјален проблем. 
Ревија за соиијална политика, год. 8, бр.11/2 Скопје, ноември 2015

Од почетоците на епидемијата па до крајот на 2013 година, во Република Македонија се дијагностицирани вкупно 197 лица, од кои повеќе од половината се потврдени во последните осум години. Пресвртот во целокупното справување со ХИВ/СИДА настанува со отворањето на Центрите за доброволно доверливо советување и тестирање во Р.Македонија (ДДСТ) и единственото Советувалиште за грижа, третман и поддршка на ЛЖХИВ при ЈЗУУ Клиника за инфективни болести и фебрилни состојби - Скопје. Од самиот почеток на Советувалиштето (2005 г.) до денес, важна улога во третирањето на социјалните проблеми на ЛЖХИВ има социјалниот работник. Додека релацијата меѓу докторот и пациентот ретко се протега надвор од клиничките или болничките врати, вложувањето на социјалниот работник достигнува до секојдневниот живот на клиентот, судирајќи се со предизвиците со кои се соочува клиентот секојдневно (Surface, 2007).Профилот на социјалниот работник е јасно издефиниран во мулитидисциплинарниот тим, кој освен медицински персонал (лекари и медицински сестри) е составен и од социјален работник и психолог. Важноста на психосоцијалната поддршка е препознаена од Светската здравствена организација според која: „Психосоцијалната поддршка се однесува на моменталните психолошки и социјални проблеми на ХИВинфицираните лица, нивните партнери, семејства и старатели (WHO, 2009)“.

\section{Важноста на психосочијалната поддршка}

Според Светската здравствена организација: ХИВ-инфекција влијае на сите димензии на животот на една личност: физички,психолошки, социјални и духовни. Советувањето и социјална поддршка може да им помогне на луѓето и нивните негуватели поефикасно да се справат со секоја фаза на инфекцијата и да влијае во подобрувањето на нивниот квалитет на живот.Проценката и интервенциите можат да бидат во насока на справување со акутно-стресната фаза по известувањето за ХИВ дијагнозата, следно во периодот на приспособување и процесот на 
справување со сознанието за ХИВ инфекцијата, до прогресија на болеста и смрт. Инфекција може да резултира со губење на социоекономскиот статус, вработувањето, приходите,домувањето и мобилноста. За поединците, нивните партнери и семејства, психосоцијална поддршка може да им помогне во донесувањето информирани одлуки, подобро справување со болестите и социјалните последици како што е дискриминацијата. Со тоа се спречува и понатамошно пренесување и ширење на ХИВ инфекцијата. При тоа психосоцијалната поддршка може да биде насочена кон одредени специфични групи на ЛЖХИВ, како на пример, жени, деца, мажи кои имаат секс со мажи (МСМ), лица кои инјектираат дрога (ЛИД), сексуални работници (СР) и др.

Спроведувањето на психосоцијалната поддршка може да биде изведувана не само од психолог и социјален работник, туку да опфати и поширок опсег на професионалци кои се оспособени да ја пружаат истата. Со соодветна обука на peer ниво - (врсничка поддршка), може да се воспостават сервиси за грижа и поддршка од волонтери или ЛЖХИВ со цел помош на други луѓе погодени со ХИВ.

\section{Едуциран и обучен професионалеч}

За успешно функционирање и работење во тимот, социјалниот работник кој третира здравствени проблеми мора да биде добро едуциран и обучен за сите фази од болеста со кој се соочуваат пациентите. Во опсегот на едукација на клинички социјален работник во многу образовни установи во светот е посебно акцентирано прашањето за работа со луѓе кои живеат со ХИВ/СИДА. Во Република Македонија третирањето на ХИВ/СИДА како социјален проблем не е опфатено ниту во курикулум за професионално оспособување на студентите по социјална работа, ниту во стучното надоградување и усовршување во нивната секојдневна работа. Улогата на невладините организации кои го таргетираат ова прашање, посебно дојде до израз изминатите години со селективни 
Ревија за соиијална политика, год. 8, бр.11/2 Скопје, ноември 2015

неформални едукации кои ги спроведуваа за различни видови на стучни профили, вклучувајќи и социјални работници.

Во работа со маргинализирани заедници како што се ЛЖХИВ од голема важност е социјалниот работник да поседува добри советувачки вештини, најпрвин како советувач за ХИВ/СИДА кој ќе дава информации за превенција и намалување на ризиците за пренос на инфекцијата. Ова подразбира познавање на начините на трансмисија на вирусот (сексуален, крвен, вертикален), вклучително и мерките на заштита, но и начините како не се пренесува вирусот. Во понатамошните интервенции, социјалниот работник мора да ги познава сите аспекти на лекувањето и самиот медицински третман на кој ќе биде подложен пациентот. Ова подразбира познавање на различните фази на инфекцијата (од ХИВ до СИДА), различните коинфекции и болести пропратени со ХИВ, добро познавање на лековите кои ги примаат пациентите и какво е нивното дејство, важноста на придржувањето на истите и како тоа може да влијае на нивниот животен стил, а сѐ со цел да даде соодветна поддршка при потенцијално кризни моменти. Навидум овие медицински податоци може да изгледаат непотребни, но познавајќи ги сите овие аспекти, социјалниот работник може да им помогне на пациентите да го зголемат разбирањето за режимот на земање на терапијата, важноста од навременото и доследно приддржување кон истата, како и очекуваните несакани ефекти кои може да имаат големо влијание на социјалното функционирање на луѓето. Како мултидисциплинарна професија, социјалната работа подразбира и добро познавање на постоечките законски регулативи од областа на здравственото и социјалното законодавство. Имено, едно од приоритетните подрачја на делување на социјалниот работник е укажување на правата и обврските кои ги имаат Луѓето кои живеат со ХИВ, можностите за добивање на различен тип на здравствен третман или социјални услуги. Покрај стучното знаење кое треба да го има социјалниот работник тој мора да поседува и одлични комуникациски вештини и способности. На самиот почеток во работа со ЛЖХИВ секој професионалец се чувствува несигурен и недоволно запознаен со 
карактеристиките и проблемите со кои се соочува оваа ранлива група на луѓе.

Потребата од постојана едукација и следење на новите трендови е повеќе од неопходна со цел ефективна помош и поддршка. Сепак, долгогодишнатата работа во помагателни професии води до професионално согорување (Burnoutsyndrome)при што треба да се земат предвид механизмите за надминување на овој синдром или нивно убалжување.

\section{Улогата на сочијалниот работник}

Зборувајќи за улогата на социјалниот работник во пружањето на помош и поддршка за ЛЖХИВ, најпрвин мора да се тргне од четирите главни типови на социјална поддршка која ја дава социјалниот работник( според House, Landis \& Umberson, 1981):

1. Информативна поддршка која вклучува обезбедување на информации, едукација или насоки за менаџирање со личните и здравствени проблеми.

Во контекс на проблемот на ХИВ/СИДА социјалниот работник овој вид на поддршка го пружа во инфомрации како што се основни податоци за болеста, начини на пренос и заштита, постоење на терапија и нејзино влијание врз секојдневното делување на поединецот, споделување на ХИВ статус со партнер/семејство, информирање за здравствени права, информации за права од социјалното законодавство, едуцирање за човекови права и заштита од стигма и дискриминација.

2. Инструментална поддршка (исто така позната како материјална поддршка) која вклучува обезбедување на материјална помош во форма на финансиска помош, материјални добра, работна сила, време или било кој друг тип на директна помош. 
Ревија за соиијална политика, год. 8, бр.11/2 Скопје, ноември 2015

Овој вид на поддршка е особено значајна за лицата кои се сиромашни или социјално исклучени. Обезбедувањето на дирекната помош во храна, лекови или финансиски средства за покривање на трошоците за патување, кај одредени ЛЖХИВ се тесно детерминирани со посетувањето на сервисот за грижа, третман и поддршка. За овие лица помошта околу справувањето со секојдневните социјални проблеми кои не се дирекно поврзани со болеста, е многу побитна отколку самиот здравствен проблем со кој се соочуваат.

3. Емоционална поддршка која вклучува обезбедување на емпатија, љубов, доверба, охрабрување, слушање и нега од членовите во социјалната мрежа на поединците.

Одредена група на ЛЖХИВ кои одлучиле својот ХИВ статус да не го споделуваат со никого, имаат најголема потреба токму од овој вид на поддршка. Имено, за нив секој разговор со стручно лице го доживуваат како емоционално празнање и добивање на потребното разбирање кое не можат да го добијат од најблиските.

4. Проценета поддршка (исто така познати како соединета поддршка и социјална интеграција) која ги вклучува бројот на општествените односи кои една индивидуа ги има со другите кои имаат заеднички интереси. Овој тип на поддршка, исто така, обезбедува афирмација и повратни информации.

Пружајќи го овој вид на поддршка социјалниот работник ги утврдува сите човекови ресурси во социјалната мрежа на клиентот при тоа советувањата и интервенциите се во насока на активирање на системот на поддршка на пациентот, мобилизирање на други лица во социјалната мрежа, но и самостојно справување во семејната и работна средина на лицето. Со овој вид на помош се јакнат капацитетите на лицата кои се засеганти со здравствениот проблем но во исто време се пружа поддршка во надминување на низата социјални проблеми кои се испреплетуваат паралелно со проблемот на ХИВ/СИДА. 
Во пракса оваа помош и поддршка од социјалниот работник подразбира негово инволвирање уште на самиот почеток на соопштување на позитивниот резултат кај лицето, па сѐ до интервенции поврзани со грубо кршење на човековите права на луѓето кои ги застапува. Во самиот пристап на работа со овие ранливи групи и засегнати страни, дијагностичките мерки и алатки мора да бидат употребени многу внимателно и временски темпирано од страна на социјалниот работник. На почетокот самите лица се исплашени и скептични во однос на институциите и лицата на кои треба да се обратат за помош, пред сѐ заради влијанието на стигмата и предрасудите кои ги носи самата болест. Во третирањето на целокупниот проблем на ХИВ/СИДА, ова можеби е единствената болест при која пациентите и семејствата повеќе се исплашени за обелоденувањето на ХИВ статусот во нивната средина, отколку самиот тек и прогрес на болеста. Тоа го наметнува и најголемиот социјален проблем со кој се соочуваат ЛЖХИВ - стигмата и дискриминацијата. Имено, најважната улога од страна на социјалниот работник е поврзана токму со ублажување на ефектите од стигмата во општеството или дискриминацијата на различни нивоа кај лицата погодени со ХИВ. Стравот од губење на пријателите и блиските, отфрлање од семејната или работна средина, непружање на здравствени или социјални услуги, се само дел од секојдневието на ЛЖХИВ. Живеејќи во една таква средина, лицата кои биле во ризик од ХИВ имаат мала мотивираност да се тестираат и да го дознаат својот ХИВ статус, а како последица на тоа се откриваат во доцен стадиум на болеста кога се губи способноста за работа и нормално функционирање.

Ефектите на стигмата и дискриминацијата се далекусежни дури и ако лицата со ХИВ навремено го дознаат својот статус. Поради стравот од „социјална смрт“ и излолација во средината, тие претпочитаат да не се дознае нивниот ХИВ статус и по цена да избегнуваат контакти со институциите за грижа, третман и поддршка. Со тоа повторно се лишуваат себе си од преземање на адекватни мерки за да не дојде до прогресија и влошување на болеста. 
Ревија за соиијална политика, год. 8, бр.11/2 Скопје, ноември 2015

Долгогодишното искуство во работа со ЛЖХИВ покажува дека голем број на советодавни постапки се спроведуваат околу прашањата за обелоденување на ХИВ статусот. Откривањето на ХИВ статусот за луѓето кои живеат со ХИВ претставува еден од најважните животни одлуки, но и најстресни моменти во нивниот живот. Прашањата : „На кого да кажам, кога е најпогодно време да кажам, ќе можам ли сам да го споделам тоа со семејството или партнерот?“, се само дел од секојдневните дилеми со кои се соочуваат ЛЖХИВ. Улогата на социјалниот работник е да му помогне на лицето да го пронајде најдобриот можен модел на сооптување на оваа информација пред блиските или партнерот за кој смета дека треба да знае. Приватноста и доверливоста меѓу социјалниот работник и клиентот е битен предуслов за осварување и градење на релацијата меѓу двете страни, акцентирајќи ја обврската на социјалниот работник за чување на професионалната тајна.

Мапирање на постоечките институционални и вонинституционални сервиси за помош и поддршка на различни таргет групи на ЛЖХИВ е уште едно подрачје на делување. Имено, социјалниот работник мора добро да ги познава постоечките служби во заедницата на ЛЖХИВ со цел обезбедување на адекватна поддршка на локално ниво. Соработка, координација и препраќање до невладиниот сектор кој ги третира прашањата на превенција и поддршка на ЛЖХИВ во Македонија е особено приоритетна дејност на социјалниот работник.

Една од вештините на акција на социјалниот работник е способноста за стимулирање и за поддршка на групите за самопомош, преку охрабрување на клиентите да соработуваат со други лица кои имаат слични проблеми и на тој начин да се обидат да го изнајдат решението за своите проблеми (Трајковска, 2002). 


\section{Специфични таргет групи на ЛЖХИВ}

Кога зборуваме за социјалните проблеми на ЛЖХИВ, не треба да се заборават спецификите на самите лица кои се засегнати од проблемот. Имено, хетерогеноста на самата заедница на ЛЖХИВ налага пристапот на работа со истите да биде приспособен на нивните потреби и карактеристики. При тоа ќе се осврнеме на дел од таргет групите кои се најзасегнати во Македонија.

Мажи кои имаат секс со мажи (MCM)

Се смета дека мажите кои имаат секс со мажи (MCM) се најзасеганти кога станува збор за пренос на ХИВ и сексуално преносливи инфекции. Според УНАИДС, кај геј-мажите и другите мажи што имаат секс со мажи веројатноста да живеат со ХИВ е 19 пати поголема, отколку кај општата популација. Како главни причини се наведуваат: високо ниво на физичко, психичко и сексуално насилството, криминализација, стигма, дискриминација и социјална исклученост, ограничен пристап до ХИВ или други здравствени сервиси и неадекватно инвестирање (финансирање) на програми кои ги засегаат MCM(UNAIDS, 2014). Дел од оваа заедница се изјаснува себе си како хомосексуалци, други како бисексуалци, додека голем број себе си се гледаат како хетеросексуални мажи кои само повремено имаат секс со мажи. Хомофобијата, стигмата и дискриминацијата која ја чувствуваат МСМ во нашето општество, води до невидливост на оваа заедница. Тоа само по себе подразбира и тешко достапни превентивни програми, отсуство на рана дијагностика и третман за оваа таргет група. Во недостатокот на организирани механизми поврзани со оваа ранлива група во рамки на јавните здравствени и социјални институции, невладиниот сектор го има приматот во превентивното делување кај МСМ заедницата во Македонија.Улогата на социјалниот работник во работа со оваа таргет група е насочена првенствено во разбирање на нивните проблеми во рамки на општествениот систем, семејството или партнерските релации. Автостигмата која е присутна кај дел од оваа заедница налага внимателен пристап во интервенциите и 
Ревија за соиијална политика, год. 8, бр.11/2 Скопје, ноември 2015

справувањето со секојдневните социјални проблеми. Дел од оваа група на погодени ЛЖХИВ живеат под притисокот на „социјална маска“" при што имаат семејства, партнери и деца кои несомнено се засегнати од проблемот на ХИВ. Справувањето со семејните нарушени односи, отфрлањето и изолацијата во рамки на примарното семејство често пати се последица на обелоденувањето на сексуалната орентација кај погоденото лице, а потоа и врз основа на здравствениот статус. Досегашната долгогодишна практика покажува дека во нашето општество Луѓето кои живеат со ХИВ, а истовремено припаѓаат на групата на МCM се соочуваат со двојна стигма и етикетирање во сите нивоа на социјално делување.

Жени

Родовата нееднаквост во социјалниот или економскиот статус, недостаток од пристап до превентивни сервиси, едукација и здравствена грижа ја зголемуваат вулнерабилноста на ХИВ/СИДА (UNAIDS, 2004). Во светот, нееднаквите сопственички права и правото на наследување, недостаток на брачни права, како и употребата на „трансакциски секс“ во замена за храна, засолниште, или други основни потреби, ја влошуваат ранливоста на жените (Wyatt, Myers, Williamsetall., 2002).

Насилството, а особено сексуалното насилство кај жените, ги прави исто така посебно ранливи при ХИВ инфекција, при што поддршката од социјалниот работник игра суштинска улога во самото зајакнување на жените и справувањето со насилството. Финансиската зависност од другите членови во семејството, посебно од машкиот партнер ја намалуваат нивната способност за самостојно донесување на одлуки поврзани со нивниот живот. Жените од етничките заедници како посебно специфична подгрупа се особено ранливи на проституција или трговија со луѓе, а во услови на живеење со ХИВ позитивен статус тоа доведува до други ризик фактори. За многу жени имањето деца е клучен фактор што ја одредува нивната значајна позиција во општеството. Затоа, да се користат бариерни методи на контрацепција или да се вклучат во 
непенетративни сексуални односи, со цел да се избегне пренесување на ХИВ е културнолошки неприфатливо, бидејќи со тоа ќе се спречи концепцијата. Неплодноста ја зголемува ранливоста на жената не само поради тоа што се намалува нејзината социјална вредност со што се влијае на нејзината економска сигурност и поддршка, но исто така затоа што во многу култури, тоа им овозможува на мажите да земат втора сопруга, па дури и да се разведе од својата прва сопруга.Ако тоа се случи, а жената не е во можност да се премажи, нејзината ранливост на ХИВ повторно се зголемува, а нејзините животни услови можат да ја натераат да се вклучи во секс за преживување (Whelan, 1999). Улогата на социјалниот работник во работа со жените засегнати од ХИВ, е со холистички пристап да им помогнат да ги надминат бариерите и да преземат контрола врз својот живот.

\section{Етнички заедници}

Покрај Македонците, најголем дел од засегнатите етинички заедници со ХИВ/СИДА во Република Македонија се Албанците и Ромите. При тоа разбирањето и прифаќањето во двете средини наидуваат на различен одговор како кај ЛЖХИВ така и во нивните семејства и партнери. Спецификите како што се: многудетно семејство, блиските релации во семејството, лојалноста, припадноста и солидарноста неретко водат кон соопштување на ХИВ статусот на поголем број од членовите на семејството. Особено треба да се нагласи фактот што понекогаш и без согласност на самото лице кое живее со ХИВ , статусот се соопштува под притисок и влијание на негови блиски.

Често пати јазичната бариера кај одредена етничка заедница налага инволвирање на други членови од семејството или други здравствени професионалци при сооптување на информациите и полесно разбирање на проблемот. Припадниците на ромската етничка заедница спаѓаат во најмаргинализираните граѓани во државата. Тие се на дното во однос на економската, општествената, а и социјалната положба, односно сигурност. Ниското ниво на 
Ревија за соиијална политика, год. 8, бр.11/2 Скопје, ноември 2015

образование кај лицата од ромска етничка заедница ги детерминира тие да бидат долгорочно зависни од социјалната помош која ја примаат од државата (ECE, 2006). Помошта и поддршката кај оваа група на лица кои живеат со ХИВ е главно во обезбедување на дополнителни матерјални и финансиски средства како полесно би ги надминале последиците од сиромаштијата. Постоечките анализи кај ромската етничка заедница покажуваат на следниве пречки во остварување на правото на здравствено осигурување: немање на потребна документација за стекнување на правото на здравствено осигурување, неинформираност, нередовно пријавување, работа во неформален сектор, недостиг на стручни Роми во јавно здравствените служби (ECE, 2006). Кај оваа подгрупа на ЛЖХИВ опфатот на интервенции на социјалниот работник се сеопсежни и целиот спектар на активности е насочен кон надминување на горепосочените пречки со кои се соочуват лицата.

Млади и деца

Младите луѓе на возраст од 10-24 години ја сочинуваат една од најранливите, но сепак занемарлива популација погодена од вирусот на хумана имунодефициенција(ХИВ).Континуираното ширењето на нови инфекции, заедно со зголемената достапност на високо активна антиретровирусна терапија(BAART)и последователното подолго преживување на децата заразени во текот на бременоста, раѓањето и првата година од животот, значи дека бројот на млади луѓе кои живеат со ХИВ најверојатно значително ќе се зголеми во текот на следните10 години (Greifinger, 2009).

Од спроведеното истражување во 2006 год. од страна на СЗО и УНИЦЕФ за тоа кои се најчестите причини поради кои младите луѓе кои живеат со ХИВ најмногу бараат психосоцијална помош се издвоени : посветеноста на терапијата, откривање на ХИВ статусот, прашања поврзани со секс, стигма и дискриминација и недостиг на мрежи за поддршка. 
Информирањето на новодијагностицираниот адолесцент за ХИВ позитивниот резултат е трауматично доживување за многу родители/старатели, па дури и за самите професионалци кои работат на ова поле. Доколку трансмисијата на вирусот настанал по вертикален пат, родителите секогаш се испречени пред прашањето дали моето дете ќе ме осудува и како да се справам со неговите емоции и реакции по дознавањето на овој факт.

Многу родители/старатели имаат големи дилеми кога е вистинското време да му соопшти на младиот човек за една ваква хронична дијагноза, особено ако подолго време знаеле и тоа го криеле од нивното дете. Отпочнувањето со терапија која е доживотна и на која младиот човек треба да се приддржува цел живот, исто така, со себе носи голем товар и за родителите/ негувателите. Одлуката што младиот човек треба да ја направи околу соопштувањето на резултатот на други членови на семејството или врсниците најчесто е пропратена со страв од неприфаќање или осуда. Самата адолесценција по себе носи многу специфики кои се збунувачки и за родителите и децата. Во доцната адолесценција сѐ до фазата на рана независност младите луѓe се соочуваат со првите партнерски врски и романтични доживувања. Споделувањето на ХИВ статусот пред потенцијалниот партнер за нив претставува тешка одлука која не секогаш се подготвени да ја донесат. Улогата на социјалниот работник овде игра многу голема важност, подготвувајќ́ го младиот човек за сите предности и ризици со кои може да се соочи во таквите интимни релации. Сексуалното однесување е во тесна релација и со конзумирањето на алкохол и психотропни супстанци што дополнително ги зголемува ризиците по младиот човек.

Доколку се работи за претшколско или школско дете одлуката дали да се каже во воспитно-образовната установа со себе носи многу предизвици. Како ќе биде прифатено од наставниот кадар, дали секојдневното функционирање на детето може да предизвика ризици за останатите деца и што ако се дознае за ХИВ позитивниот статус на самото дете? Во случај на загубата на родителите поради болест од СИДА, детето може да има длабоки емоционални, економски и 
Ревија за соиијална политика, год. 8, бр.11/2 Скопје, ноември 2015

развојни последици, особено во сиромашните домаќинства. Децата без родители или децата под старателска грижа восиромашните домаќинства можеби ќе треба да заработат за живот на улица или за слабо платена работа, каде тие уште повеќе се изложени на ризик од глад, болест или сексуална експлоатација, а како последица на тоа и дополнителни здравствени и социјални ризици.

\section{Сиромашни лица}

Постои општа согласност дека сиромаштијата е неможност да се задоволат нечии основни потреби, како храна, облека, домување, хигиена, како и основните услуги како што се здравствена заштита и образование. Заедничка асоцијација на сиромаштија е недостиг од пари и можности за вработување. Најефективни активности од социјалниот работник во намалувањето на сиромаштијата на ниво на домаќинство или општествено ниво вклучуваат мобилизација на ресурси, градење на капацитети, организација на заедницата, советување и поддршка на деца во едукација (Twikirize,Asingwireetall., 2013). Секако дека за лицата кои живеат на работ на сиромаштија, соочувањето со неповолна здравствена состојба носи дополнителен товар со кој мора да се справуваат. Нерегулирано здравствено осигурување, неадекватен здравствен третман, недостаток на храна, лекови или домување се само дел од проблемите со кои се погодени овие лица.

Земајќи ја предвид социоекономската компетенција на лицата кои се засегнати со ХИВ, може да се констатира дека главен проблем кој првенствено ги засега е проблемот на задоволување на основни егзистенцијални потреби, а дури потоа здравствениот проблем. Тоа само по себе води до недоволно сериозен пристап во земање на терапијата или пак посетување на здравствени институции. Улогата и интервенциите од социјалниот работник при работа со сиромашни ЛЖХИВ е минимизирање на последиците од лошата финансиска криза на семејството, невработеноста и отфрленоста од општеството. Вулнерабилноста на ова категорија на луѓе сама по себе води и до поголеми растројства во нивното ментално здравје и зголемено 
чувство на немање контрола над сопствените животи. Токму кај оваа заедница психосоцијалната поддршка од страна на социјалниот работник е најнеопходна во утврдување на потребите на лицата и делување на терен за задоволување на истите.

\section{Заклучок}

Социјалната работа во институционалната здравствена заштита е насочена кон помош на клиентите/пациентите со психосоцијални проблеми предизвикани од болест, од хоспитализација или од потребата од медицински третман (Трајкова, 2002). Социјалниот работник кој работи со луѓе кои живеат со ХИВ во рамки на здравствена установа е несомнено неопходен профил во третирањето на проблемите на засегантите лица. Неговите знаења и вештини вклучуваат голем број на превентивни активности со цел заштитување на правата и интересите на луѓето кои живеат со ХИВ, но и останатите во општеството, преку советодавната функција до решавање на конфликтни ситуации при кршење на човековите права.

На индивидуално ниво, социјалните работници обезбедуваат широк спектар на услуги и поддршка за лицата кои живеат со ХИВ/ СИДА.Социјалните работници се запознаени со ресурсите на заедницата, како што се административните процедури за социјална помош, програмите за едукација/обука и планирање на кариерата, програмите и политиките за снабдување со лекови, краткорочни и долгорочни програми за инвалидност, домување, законите за човекови права, услуги за третирање на зависности, правни услуги, услуги и ресурси за луѓето кои се геј, лезбејки, бисексуалци, исхрана и обезбедување на храна. Социјалните работници често работат со лицата кои живеат со ХИВ/СИДА за да ги насочат кон овие системи, а во исто време ги зајакнуваат клиентите да донесуваат информирани одлуки кои влијаат на нивното здравје (Schultz, 2011).

Во контекст на заедницата, социјалните работници продолжуваат да застапуваат во име на оние кои живеат со 
Ревија за соиијална политика, год. 8, бр.11/2 Скопје, ноември 2015

ХИВ/СИДА преку организирање на заедницата и развојот на политиките.Тие исто така обезбедуваат едукацијаза да се намали инциденцата на ХИВ преку намалување на штети и промоцијата на здравјето. Социјалните работници се свесни дека здравствената грижа е повеќе од медицинска нега. Социјалните работници се трудат да се искорени социјалната исклученост и сиромаштијата во сите области на делување.

Во своите напори за обезбедување континуирана и долгорочна психосоцијална поддршка на ЛЖХИВ државата треба да преземе дополнителни чекори во идентификација на потребите и обука на соодветни кадри (на пример, социјални работници, советници, психолози). Тоа ќе биде важен чекор на национално ниво за да се осигура дека психосоцијалната поддршка ќе биде остварлив дел од грижата за ЛЖХИВ, нивните семејства и нивните негователи. Малку информации се достапни за ресурсите кои се потребни за обезбедување на психосоцијална поддршка за лицата кои имаат ХИВ/СИДА. Таквата грижа или ретко се предвидува, или не е документирана- или се предвидени како дел од целокупната грижа и поддршка на лицата со ХИВ/СИДА (на пример, по пат на услуги домашна нега, палијативна нега итн). Како што е наведено погоре, основната психосоцијална поддршка може да се обезбеди од страна на социјални работници и инкорпорирано во болниците и клиниките.Понатаму, групи во заедницата може да бидат обучени за обезбедување на психо-социјална нега.Со оглед на важноста на овие услуги во целокупното здравје и поддршка на лицата со ХИВ/СИДА, нивните семејства и негуватели, социјалните работници треба да бидат вклучени како интегрален дел во грижата и поддршка на ЛЖХИВ. 


\section{ЛИТЕРАТУРА}

Greifinger R., (2009) A qualitative review of psychosocial support interventions for young people living with HIV. Geneva, WHO

Hayes, A. (2007). Women's Vulnerability to HIV/AIDS: A Global Examination

House, J.S., Landis, K.R., \& Umberson, D. (1988). Social relationships and health. Science, 241, 540-545.

Park, M. (2005). The global HIV/AIDS epidemic: HIV/AIDS policy fact sheet. Kaiser Family Foundationwww.kff.org

Schultz C., (2011) Social work practice http://www.casw-acts.ca/en/social-workpractice-hivaids

Surface, D. ( 2007). HIV/AIDS Medication Compliance: How Social Support Works. Social Work TodayVol. 7 No. 5 P. 20

Трајковска С.В., Белевска Д, ( 2002). Клиничка социјална работа. Скопје: Ѓурѓ́

Twikirize J. M., Asingwire N., et all., (2013). The Role of Social Work in Poverty Reduction and the Realisation of Millennium Development Goals in Uganda www.fountainpublishers.co.ug

UNAIDS (2014). The Gap Report http://www.unaids.org/sites/default/files/media_asset

UNAIDS. (2004b). Women and AIDS: A growing challenge. UNAIDS Epidemic Update 2004www.unaids.org

Wyatt, G., Myers, H., Williams, et all. (2002). Does a history of trauma contribute to HIV risk for women of color: Implications for prevention and policy. American Journal of Public Health 92 (4), 660-665.

Whelan, D. (1999). Gender and HIV/AIDS: Taking stock of research and programmes. Geneva, UNAIDS

Здружение за еманципација, солидарност и еднаквост на жените во РМ, (2006). Анализа на состојбата на Ромите во Република Македонија во однос на опфатот со здравствено осигурување. Скопје: ФООМ

Здружение за еманципација, солидарност и еднаквост на жените РМ, (2006). Ризични фактори кај ромската популација по однос на феноменот трговија со луѓе. Скопје: ФООМ 
